\title{
CRITERIA OF ECONOMIC EFFICIENCY OF LAND STOCK MANAGEMENT
}

Gabibulla KHASAEV, Samara State University of Economics, Samara, Sovetskoi Armii Street, 141 Russia, rector@ sseu.ru Alexandr VLASOV, Samara State University of Economics, Samara, Sovetskoi Armii Street, 141 Russia, vasilievadi@mail.ru Dariya VASILIEVA, Samara State University of Economics, Samara, Sovetskoi Armii Street, 141 Russia, vasilievadi@mail.ru Velta PARSOVA, Faculty of Rural Engineering, Latvia University of Agriculture, Akademijas st.19, Jelgava, LV-3001, Latvia, velta@parsova.lv (corresponding author)

One of preconditions for sustainable socio-economic development of the region can be observed as much as possible involvement of land resources in economic turnover and increasing of efficiency of their use.

On the example of Samara region which is the subject of the Russian Federation are made proposals for establishment of criteria for assessment of economic efficiency of land management in specific area. Statistical data on collection of land payments (land tax and leasehold payment) in 27 municipalities of Samara region in 2004-2014 are analysed. There is investigated common information on Samara region - location, total land stock area, agricultural land area, distance between main city of region and territory, number of inhabitants, density of population, etc. Methods of mathematical statistics, regression and factor cluster analysis are used. During the research, methods of mathematical statistics, including correlation and regression analysis, were used. The indicators most influencing the volume of land payments are determined and is developed the model of coherence between level of payments and geographical and demographic characteristics of the municipality (according to the 2012-2014 data). The model allows to estimate the "normative level" for each region according to objective characteristics and to rank the regions according to this indicator. The level corresponding to such a ranking can be considered as a criterion for the effectiveness of land management taking into account the different potentialities of the municipal districts of the Samara region.

Land payments are local taxes, therefore they are an important source of the formation of financial basis of local governments in Russian Federation and play an important role in the socio-economic development of the regions.

Keywords: criteria of economic efficiency, governance, land stock, land payment, land tax, leasehold payment, leasehold

\section{INTRODUCTION}

\section{Importance of the problem}

Land resources of a country is the basis of the national wealth and an important source of economic growth and development. Economic transformation in Russia showed the significance of land management and land ownership. The key problem of the land reform in Russia was the formation of efficiently functioning management system of land resources. However, this problem has not been fully dealt with until now.

The aim of land management is to provide for the needs of the state and society: high level of economic, social and ecological conditions for people; formation of economically and socially grounded land payment system; preservation and restoration of environment, especially land resources, development of entrepreneurship and social activities etc. Management of land resources includes a wide range of social relationships - political, administrative, legal, scientific, economic, innovative, and others. The object of management is the whole land stock of the Russian Federation, its subjects, municipalities (administrative regions, cities etc.) as well as land properties having specific forms of usage, legal status etc. (Varlamov et al., 2014).

Management of land resources is implemented at several levels: national (implemented by public institutions, they have regional characteristics and refer to all categories of land regardless of a category of land and the rights for the land plot); sectoral or industrial (implemented by ministries, committees, federal institutions, but there is no regional impact); local or municipal (implemented by self-government institutions in the territories of municipalities such as administrative regions, cities and other settlements); private ownership (implemented by proprietors, owners and users of land plots.

\section{LITERATURE REVIEW}

Each municipal body in the Russian Federation has local budget. The consolidated budget of a municipal region is made up of budget of the municipal region and the total amount of budgets of urban and rural settlements included in 
the municipal region. Article No 6 of the Budgetary Code of the Russian Federation states that budget is a way of creation and expenditure of financial resources intended for financial provision of tasks and functions of local governments. The Federal Law "On General Principles of the Organization of Local Self-Government in the Russian Federation" contains the main provisions characterizing the peculiarities of local budgets (Varlamov, 2014; Khasayev et al, 2016).

The Tax Code of the Russian Federation (hereinafter - Tax Code) provides that local taxes include only two taxes: land tax and personal property tax. Local taxes and fees are compulsory for payment in the territory of the respective municipality (Law of the Russian Federation \#1738-1).

The basis for calculating the land tax is the amount of cadastral value of one hectare of the corresponding category of the land reserve of a municipality. According to the Tax Code, land plots located within the municipality on whose territory tax is imposed are considered to be the objects of taxation. Leasehold payments are charged for land plots rented to users. The procedure of determining the amount of leasehold payments, as well as the procedure, conditions and terms for making lease payments for the use of land plots, whose state ownership is not delimited, is established by the state authorities of the Russian Federation. To determine the amount of leasehold payment for a land plot that is in the state or municipal ownership, the cadastral value of this land plot is applied.

\section{Concept Headings}

Objective. Samara region occupies an area of 53.6 thousand $\mathrm{km}^{2}$ or $0.31 \%$ of the whole territory of Russia. Samara region is included in the Volga Federal province and in the Volga Economic Region. It comprises 10 urban districts and 27 municipal regions (Fig. 1). The number of population is 3,215.7 thousand people (2010).

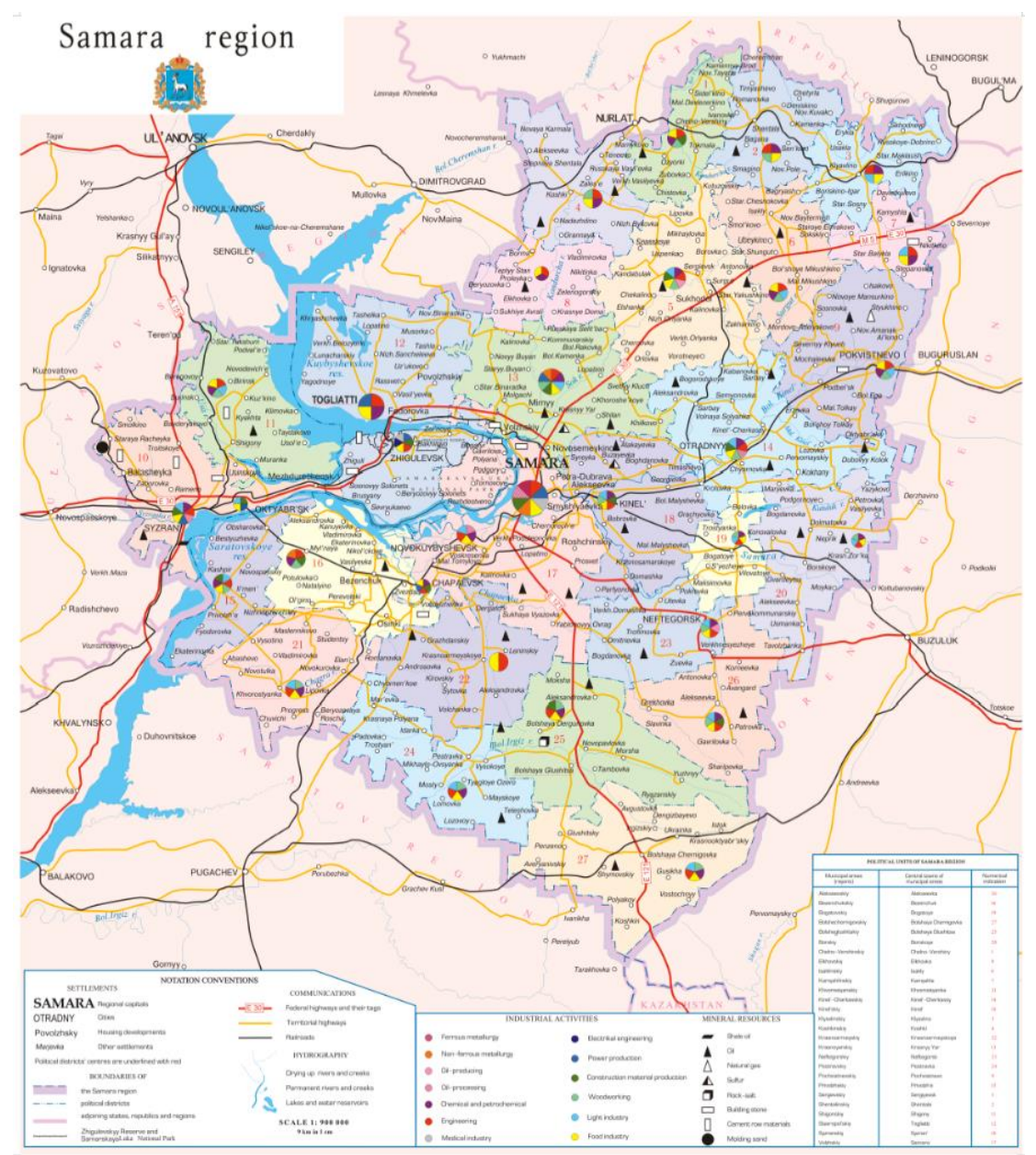

Figure 1. Scheme of administrative-territorial division of Samara region

The public report on status, condition and use of land in Samara region on January 1, 2016, shows that its largest proportion is occupied by agricultural land (75.9\%), forest land covers $10.3 \%$, residential settlements account for $6.7 \%$, areas of industry, transport and other specialized usage cover $1.3 \%$, protected natural areas $-2.6 \%$, water bodies $-3.1 \%$, land reserve $-0.1 \%$ of the area of the region (Report ..., 2016). The structure of the land of the Samara region is depicted in Figure 2. 

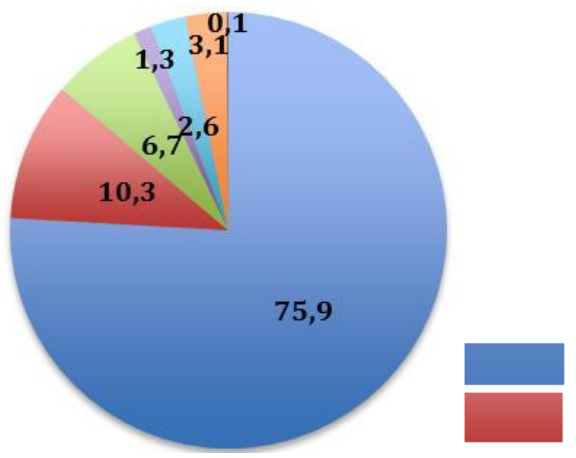

agricultural land forest land

Figure 2. Structure of the land of the Samara region

On average, municipal districts of Samara region differ in a number of indicators. The total area of administrative units vary from 824 to $3662 \mathrm{~km}^{2}$, the area of settlements vary from 38 to $158 \mathrm{~km}^{2}$, rural areas - from 748 to $2743 \mathrm{~km}^{2}$. The most remote districts are Shetalinsky and Shigonsky districts which are located $200 \mathrm{~km}$ from the centre, the amount of the population of administrative units varies from 10 to 84 thousand people.

Payment for land use was introduced in Russia on 1 January, 1992, after adoption of the Law "On payment for land" (Law of the Russian Federation \#1738-1), which provides the following types of fees: land tax and leasehold payment. The land tax, despite a relatively low share in the total revenue, is an important source of the formation of the financial base of local governments in the Russian Federation (The Tax Code of the Russian Federation, 2000).

The land tax is determined simultaneously by the Tax Code of the Russian Federation and laws in the cities of federal significance: Moscow, St. Petersburg, Sevastopol, but in municipalities the land tax is determined also by the laws of these municipalities as the subjects of the Russian Federation. When imposing the tax, representative bodies of municipal formations determine procedure and terms, as well as tax rates within the limits established by the Tax Code. In addition, they may set tax deductions, their criteria and application procedure including setting the amount of the taxfree amount for certain categories of taxpayers.

The methodology of the study was based on the use of the apparatus of mathematical statistics to analyze the relationship between indicators of the collection of land payments and socio-economic indicators of municipal areas. A correlation analysis was performed, revealing the key factors affecting the level of land payments of the district. Regression dependences of the level of payments on these factors have been constructed. Proposals on the use of such dependences for assessing the economic efficiency of managing the land fund in municipal districts are presented. These proposals are based on the efficiency of payments growth taking into account the specifics of each district, which makes it possible to separate the influence of the quality of land management from the objective advantages and difficulties associated with the geographical location, population density,

\section{RESULTS AND DISCUSSION}

The analysis of the dynamics of land payments in the time period from 1992 to 2014 showed a stable increase in all of the municipal districts of Samara region. But in the time period from 2004 to 2014 there was a significant accelerated growth of land payments throughout Samara region, although with some deviations. The data on the collection of land payments in the municipal districts of Samara region were used to calculate the following indicators: minimum, maximum and average values, median, lower and upper quartile, standard deviation and variation (Table 1).

Table 1. Dynamics of land payments in the municipal districts of the Samara region 2004-2014 (thous. roubles per km²).

\begin{tabular}{|c|c|c|c|c|c|c|c|c|c|c|}
\hline $\begin{array}{c}\text { Indicators of } \\
\text { land payments }\end{array}$ & $\mathbf{2 0 0 4}$ & $\mathbf{2 0 0 5}$ & $\mathbf{2 0 0 6}$ & $\mathbf{2 0 0 7}$ & $\mathbf{2 0 0 8}$ & $\mathbf{2 0 1 0}$ & $\mathbf{2 0 1 1}$ & $\mathbf{2 0 1 2}$ & $\mathbf{2 0 1 3}$ & $\mathbf{2 0 1 4}$ \\
\hline Minimum & 1,955 & 689 & 586 & 713 & 930 & 3,798 & 3,567 & 6,752 & 7,614 & 7,771 \\
\hline Median & 5,020 & 4,134 & 2,880 & 4,146 & 5,683 & 10,855 & 16,355 & 17,395 & 15,858 & 19,178 \\
\hline Average & 6.000 & 4.857 & 4.070 & 7.016 & 8.203 & 16.840 & 19.823 & 23.094 & 20.934 & 25.240 \\
\hline Maximum & 27.809 & 16.374 & 17.379 & 36.802 & 38.195 & 70.475 & 70.487 & 70.034 & 57.636 & 83.229 \\
\hline Lower quartile & 2.974 & 3.146 & 1.339 & 1.763 & 2.961 & 9.163 & 9518 & 12.862 & 11.314 & 11.524 \\
\hline Higher quartile & 7.218 & 6.113 & 6.073 & 9.821 & 10.473 & 20.601 & 24.863 & 28.248 & 24.993 & 36.337 \\
\hline $\begin{array}{c}\text { Standard } \\
\text { deviation }\end{array}$ & 5.035 & 2.979 & 3.750 & 7.745 & 7.760 & 14.425 & 1.5646 & 15.771 & 13753 & 18.997 \\
\hline Variation, \% & 84 & 61 & 92 & 110 & 95 & 86 & 79 & 68 & 66 & 75 \\
\hline
\end{tabular}

Source: own study

It should be noted that fluctuations in the variation of land payments (the ratio of the standard deviation against the average value of the indicator for the year) by regions are closely correlated with changes in the total volume of payments. 
At the same time, the increase in the heterogeneity of the districts in this indicator was observed during periods of a relatively sharp increase in the total aggregate collection of land payments, for example, 2007 (Fig. 3, 4.). Fig. 4 and 5 shows the summary dynamics of indicators of collection of land payments for the Samara region as a whole.

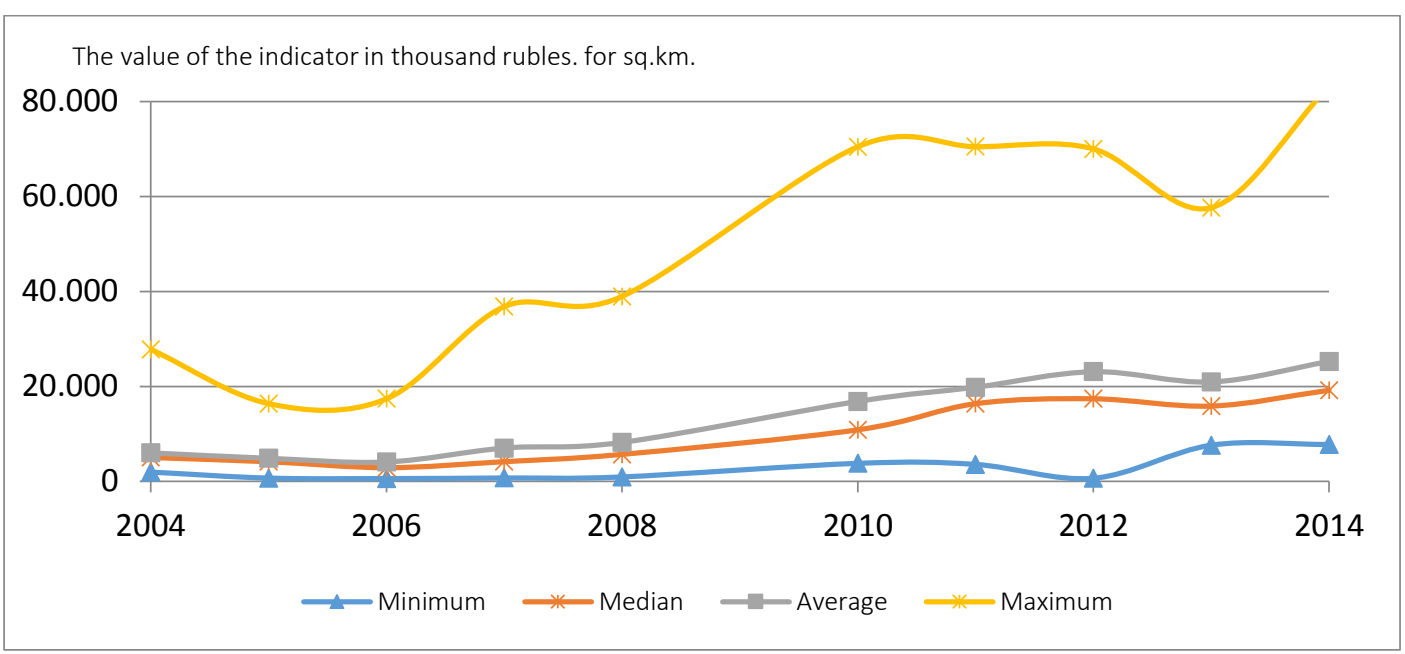

Figure 3. Dynamics of land payments in municipal districts of Samara region (thous roubles per $\mathrm{km}^{2}$ )

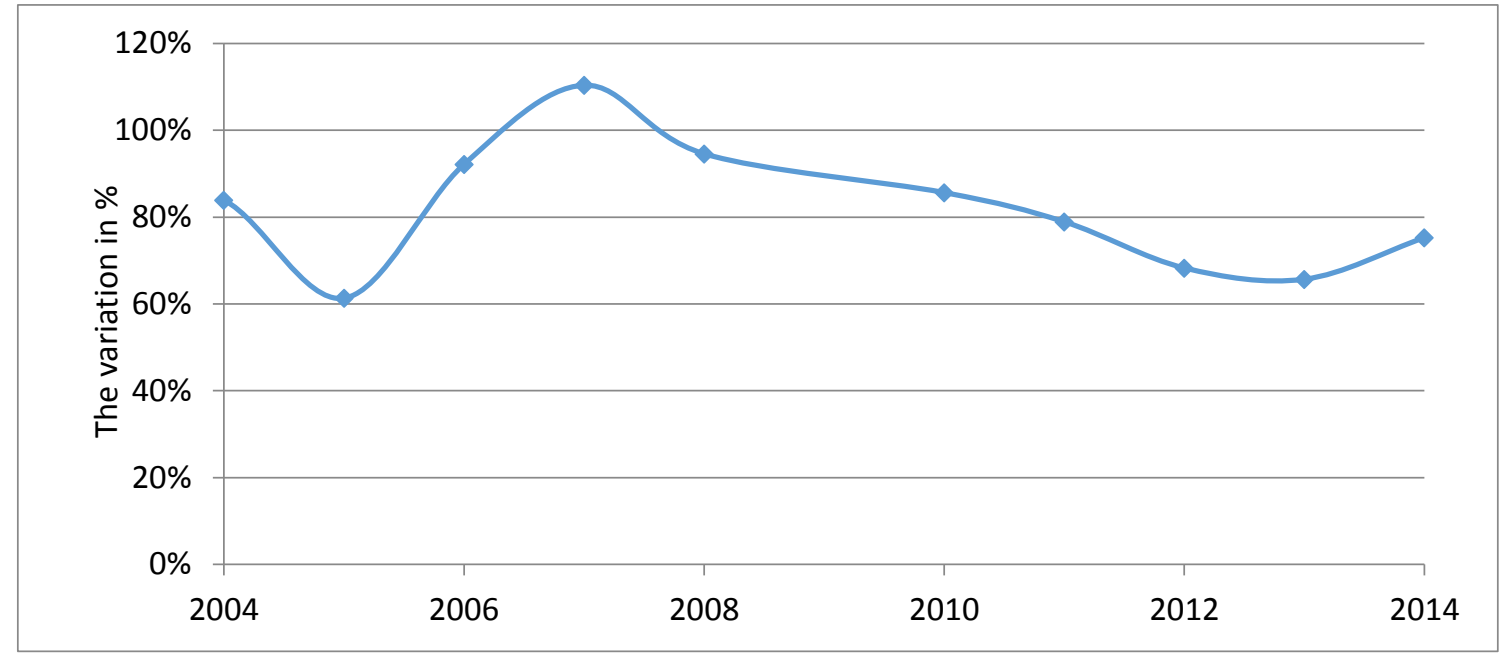

Figure 4. Variation of land payments per $\mathrm{km}^{2}$ in districts of Samara region

The analysis of the dynamics and level of collection of land payments in the municipal districts of Samara region allowed to create their ranking on the basis of the sum of two indicators. The first of these indicators reflects the distribution of areas by the total volume of payments in the time period between 2004 and 2014 .

The first indicator reflects distribution of districts regarding the total amount of payments in the time period of 2004-2014. The highest rank ( 2 points) corresponds to the ranging of a district in the higher quartile, but the lowest rank (0 points) corresponds to ranging in the lower quartile, but the intermediate rank (1 point) corresponds to the average group of $50 \%$ of districts: they fit neither in the higher quartile nor in the lower quartile. The second indicator reflects the dynamics of the "place" of each municipal district in terms of the amount of land payments over the same period. Regions that in these years were ranged in the top quartile (25\% of the best in the corresponding year) more than in a half of the cases, the highest number ( 2 points) were given. Regions that were ranged in the lower quartile ( $25 \%$ of the worst) in more than a half of the cases, the lowest number ( 0 points) were given. The rest of districts received intermediate number (1 point). The last ranking in the method was performed and analysed in the previous research (Khasaev et al., 2017).

An important issue in the analysis of the dynamics of collectability of land payments of municipal districts is the assessment of the effectiveness of local self-government bodies in managing the land reserve of the region. The existing objective factors, for example, the location of a district, its area, the density of the population, etc., may hamper effectiveness of management. Therefore, the modelling of the dependence of the level and dynamics of land payments in 2004-2014 on geographical and demographic characteristics of the municipal district was carried out (Table 1). Analysis of the correlations made it possible to conclude that the density of the population and the total population in the district are most affected by the specific land payments (from a square kilometer). The construction of regression models of the dependence of specific land payments on these factors led to the conclusion that this dependence is well described by linear, and multiplicative (power and exponential) models. Three models were calculated, which analysed the above mentioned dependence appropriately. A linear model proved more suitable for the coefficient of determination, but the power multiplicative model proved more suitable in relation to percentage deviations. 


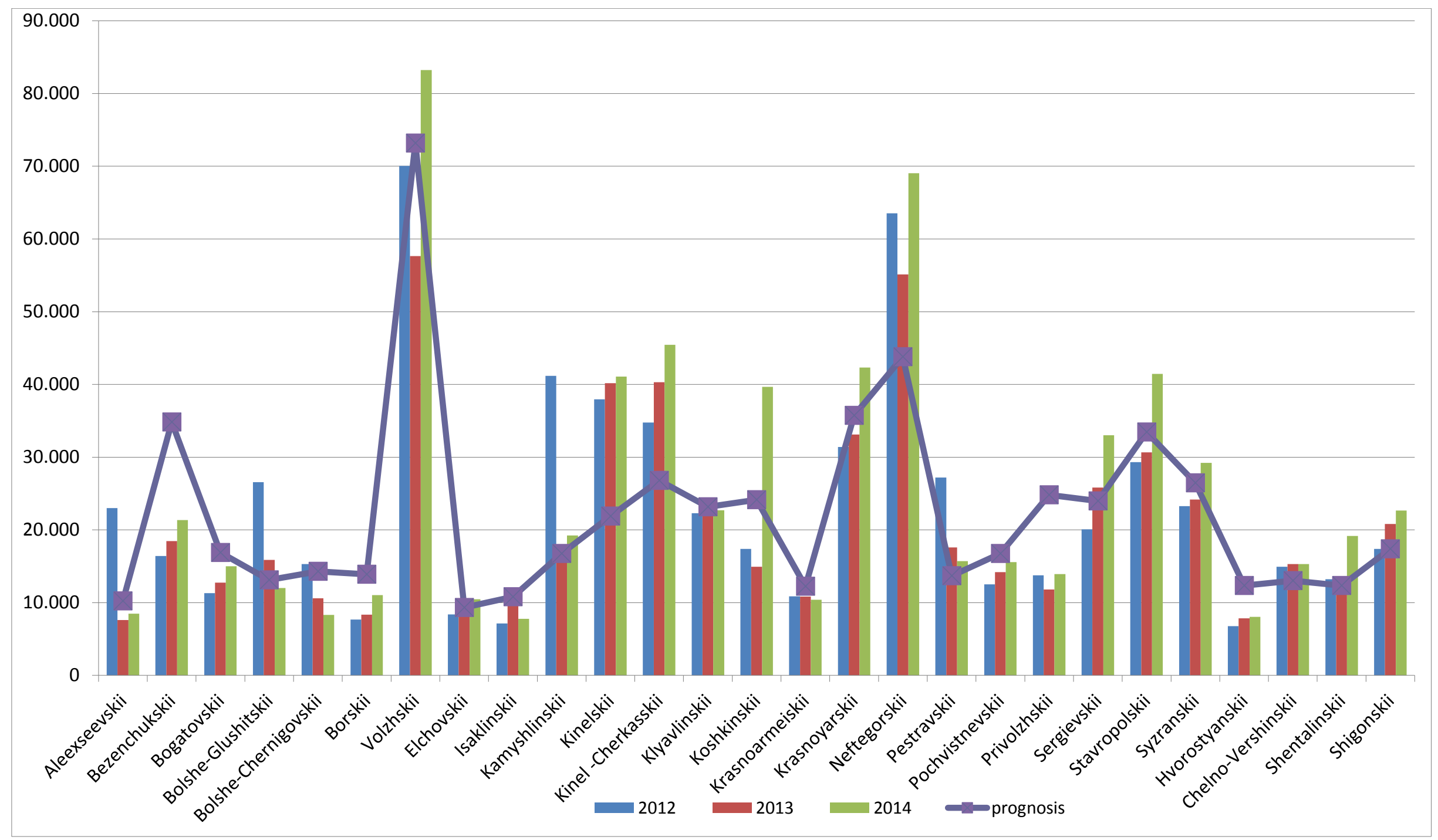

Figure 5. Specific land payments in municipal districts in comparison with average level of a standard model. 
Proceeding from the main task of modelling defined above, which was a comparison of municipal districts regarding the effectiveness of collection of land payments, the power multiplicative model was chosen for the further analysis. The Student's t-test comparison found that all the coefficients of this model were statistically significant at a significance level of alpha equal to 5\%. The construction of the model made it possible to calculate the "standard level" for each municipal district, as well as to classify areas with high and low levels of collectability of land payments (Khasaev et al., 2016). The results of modelling are depicted in Figure 5.

\section{CONCLUSION}

Thus we can observe a steady increase in the collection of land payments in Samara region for the period of 2004 2014, although the growth rates for municipal areas vary significantly.

The analysis of the dynamics for the period of 2004-2014 allowed to suggest the criteria based on regression models for the identify effectiveness of the land administration system at the municipal level. Management effectiveness is an economic category that demonstrates the contribution of land administration authorities to the overall result, which is the achievement of the land management objective. Criteria for the effectiveness of management in this case can be the results of activities and the degree of achievement of goals and objectives; one of the main ones currently is to increase the revenues of the local budget from the proceeds of land ownership.

When analyzing the collection of land payments by municipal districts of Samara region, it is important to assess the contribution of local government activities in the context of objective factors that limit their possibilities. If, for example, one of the districts is significantly ahead of another regarding land payments per unit area, it is quite possible that this is due to its location, population density, etc. In this case, the contribution of the local self-government bodies of the district is not so great. It may be that their efforts in this area deserve a lower estimate than the other region with unfavorable objective characteristics (Khasaev et al., 2017).

There is a problem of the distribution of influence of the objective characteristics of the municipal district and the quality of management of this process on the collection of land payments, for example, implementation of municipal land supervision. One approach to the solution is modelling the dependence of the level of land payments on the geographical and demographic characteristics of the municipal district. The construction of such a model will make it possible to estimate a "standard level" for each municipal district corresponding to the result that an "average region" would receive with these objective characteristics. Such an assessment will identify areas with high and low levels of collectability of land payments, which, correspondingly, could exceed the "standard" level or vice versa.

Thus, it is necessary to further improve the efficiency of land administration at the municipal level. This requires improving of the theoretical and methodological provisions for land management, which will lead to an increase of the taxation base, collection of taxes, attraction of additional investments for the development of municipalities, as well as create an effective system for ensuring the rights of stakeholders in land relations.

\section{REFERENCES}

1. Varlamov A.A. 2014. System of state and municipal management. M.: State University for Land Management, $452 \mathrm{p}$.

2. Varlamov, A.A., Galchenko, S.A., Smirnova, M.A., Shapovalov, D.A., Komarov, S.I.. 2014. Land management - an electronic textbook. Moscow, $125 \mathrm{p}$.

3. Khasayev, G.R., Vlasov, A.G., Vasilieva, D.I., Klimovsky, A.P., Lobanov, V.P., Volodina, T.V., Safonova, O.V. 2016. Analysis of the dynamics of the collection of land payments in a subject of the Russian Federation (on the example of the Samara region). News of higher educational institutions "Geodesy and aerial photography". No. 6, pp. 55-63.

4. Khasaev, G.R., Vlasov, A.G., Vasilieva, D.I. 2017. Modeling and analysis of the collection of land payments in the municipal areas, depending on the economic and geographical factors. Baltic surveying, Vol. 6, pp. 71-79.

5. Law of the Russian Federation of 11.10.1991 No. 1738-1 "On payment for land". [In Russian]

6. Report on the state and use of land in the Samara region in 2015. 2016. Federal Service of State Registration, Cadastre and Cartography Department of the Federal Service for State Registration, Cadastre and Cartography of the Samara Region. - Samara.

7. The Tax Code of the Russian Federation (part two) of 05.08.2000 No. 117-FZ (Assessed on 03/07/2016). [In Russian] 